The Social Sciences 14 (6): 255-265, 2019

ISSN: $1818-5800$

(C) Medwell Journals, 2019

\title{
Fiscal Multiplier in Egypt: A SVAR Approach
}

\author{
${ }^{1}$ Yousra Nafie and ${ }^{2}$ Baher Mohamed Atlam \\ ${ }^{1}$ Department of Economics, Benha University, Fareed Nada Street, \\ 13511 Benha, Qalubiya Governorate, Egypt \\ ${ }^{2}$ Department of Economics, Faculty of Economics and Political Science, \\ Cairo University, Giza, Egypt
}

\begin{abstract}
In this study, we empirically estimate the fiscal multiplier in Egypt using a Structural Vector Autoregressive Model (SVAR) with quarterly data for the period 1990-2015. The estimation results show that the fiscal multiplier was positive and $>1$ during the first year, then turned negative for the subsequent years. Our results suggest that the low fiscal multiplier is an indication of the weak impact of government spending on real GDP during the period of the study. We argue in the study that low value of the fiscal multiplier is due to the rising shares of subsidies and debt services cost in government spending.
\end{abstract}

Key words: Fiscal multiplier, structural vector autoregressive model, Egypt, estimationt, empirically, debt services

\section{INTRODUCTION}

The recent political unrest and economic turbulence in Egypt refocused the attention of policy makers and economists on fiscal multiplier as a potentially strong tool in stimulating economic growth. Since, decades there was a global tendency from the governments as well as international economic institutions like International Monetary Fund (IMF) to opt large fiscal stimulation during economic downturn. IMF as an austerity institution provide the Egyptian government by reforming packages, since, 1990's like Economic Reform and Structural Adjustment Programme (ERSAP) which mainly aimto cut spending through tighter fiscal and monetary policy. In addition, on November 2016, the executive board of IMF approved 3 years extended arrangement under the Extended Fund Facility (EFF) for Egypt for the amount of US\$12 billion to support authorities economic reform program. This program also, mainly aimed to reduce fiscal deficit through increasing tax revenue by introducing Value Added Tax (VAT) and cutting government spending through reducing the subsidies. However, the eventual effects of this reform packages are still uncertain. This may raise the importance of knowing the size of the fiscal multiplier for the governments before making the decision of applying expansionary or contractionary fiscal policies. Basically, if fiscal multiplier is high, fiscal policy has a large impact on the real economic output. And it may also, indicate that the government must be carful when considering austerity actions. In case of spending cut or tax increases may have devasting effects on the economy and in contrast, if the fiscal multiplier is small, this indicates the expansionary fiscal policy have a magnitude impact on the economy while the cutting government spending and increasing taxes will be more efficient in case of negative fiscal multipliers.

This study is a first attempt to provide empirical estimates for the size of fiscal multiplier using non recursive identification method specifically for Egypt. There are very few attempts in developing countries have been made to apply this methodology to calculate the size of fiscal multiplier. In Egypt, there are only three recent studies focused in estimating the size of fiscal multiplier. Alnashar (2017) focused on the effectiveness of fiscal multiplier by applying vector error correction model Sarangi and Bonin (2017) and (Cerisola et al., 2015) applied recursive SVAR. Our study hopes to fill the gap in the Egyptian literature by applying the non-recursive methodology. The study will apply Structural Vector Auto Regression (SVAR) a non-recursive strategy first used for the study of fiscal policy by Blanchard and Perotti (2002) using quarterly data for the period 1990-2015.

Theoretical background and related research: The fiscal multiplier theory originates from the major difference between classical view and Keynesian view. In the classical view, saving create investment and the equality

Correasponding Author: Yousra Nafie, Department of Economics, Benha University, Fareed Nada Street, 13511 Benha, Qalubiya Governorate, Egypt 
between the saving and investment is brought by the variation in the interest rate. While in the Keynesian view, Keynes rejected that investment is created by saving. Also, Keynes rejected that the natural interest rate will bring investment and saving to equality. Hence, Keynes introduced the multiplier as a mechanism by which investment and saving are brought to equilibrium. The multiplier process suggest that saving is created by investment through increasing income which in turn increase saving to the desired level. Also, Keynes distinguishes between the private and public investment spending when the private investment isn't sufficient to generate full employment, the government should fill the gap by public investment expenditure to help increase national income. In contrast to the classical view, Keynes considered saving as a leaking of purchasing power which disturb the income generating system. In other words, Keynes considered investment as an injection to the economy will generate income which in turn, induce the demand for consumption goods until the leak out (saving) brought to equality with investment. The greater the level of investment and the lower the proportion people decide to save from their income, the higher the level of effective demand for goods and services. Based on the above, we can define that the Keynesian view of the multiplier is telling us how much the employment has to be increased to yield an increase in the real income sufficient to increase the extra saving where the marginal propensity to consume has to be smaller than one and the increase in aggregate income will be by an amount which the value of the multiplier time the increase in investment expenditure.

After, the ideas that originated from Keynes was reinterpreted by Hicks (1937) by introducing. IS-LM Model the work by Hicks (1937) can be called the neoclassical synthesis in the neoclassical view agents expectations are introduced. All agents are rational to maximize their utility within economic constraints. In other words, consumers maximize their consumption of goods and services and their income is rationally allocated based on the willingness to pay for each good and service. Suppose in the IS-LM Model, the aggregate demand is separable from the aggregate supply then the aggregate demand depend on the fiscal policy and monetary policy while the aggregate supply depend on depend on the available technology labor and capital. The market price adjusts towards the expected price level to fill the output gap toward the full employment. Then, the fiscal multiplier will be close to zero when the price level are very responsive to the changes in the level of aggregate output while if the price levels are sticky or relatively fixed, then the fiscal policy will have larger impact on economic performance with relatively large multipliers connected to government spending. The government fiscal intervention by increasing government spending, should be associated by central bank keeping interest rate stable and therefore not reacting to the change in aggregate demand which finally will result in a larger impact of fiscal multiplier.

The models that relies on the neoclassical synthesis are Real Business Cycle (RBC). RBC models assume that the increase in government spending will completely neutralized by reduction in private consumption. In RBC models, prices are fully flexible with perfect competition. The rational forward-looking agents will expect higher taxes in the future after the increase in the government spending. If the government spending is financed by non distortionary taxes (temporary shock), then out put will rise. In contrast, if the government spending is financed through distortionary taxes (permeant shock), then both output will decrease and the fiscal multiplier turn to be negative. Gechert and Will (2012) and Leeper et al. (2017) are examples of studies applies RBC models. Further after, new Keynesian models assumes nominal terms rigidity and monopolistic competition with money introduced using money utility function.

Christiano et al. (2011) and Bhattarai and Trzeciakiewicz (2017) are examples of studies applied new Keynesian models. In general, fiscal multiplier refers to change in output $\Delta \mathrm{Y}$ that occurs after an exogenous one unit change in fiscal policy instrument, i.e., government spending $\mathrm{G}$ or taxes T. For example:

$$
\frac{\Delta \mathrm{Y}_{\mathrm{t}_{0}}}{\Delta \mathrm{Z}_{\mathrm{t}_{0}}}
$$

Where:

$\mathrm{Y}=$ Output

$Z=A$ fiscal instrument either government spending or taxes

The multiplier in the future period $n$ can be expressed as follows:

$$
\frac{\Delta Y_{t_{0+n}}}{\Delta Z_{t_{0}}}
$$

Since, there are lags in the effect, the cumulative multiplier can be defined as the cumulative change in the output over the cumulative change in the fiscal policy instrument at time horizon goes from 1 to $n$ :

$$
\frac{\sum_{i=1}^{\mathrm{n}} \Delta \mathrm{Y}_{\mathrm{t}_{0+\mathrm{i}}}}{\sum_{\mathrm{i}=1}^{\mathrm{n}} \Delta \mathrm{Z}_{\mathrm{t}_{0+1}}}
$$


Literature review: Most of the empirical studies in the literature of fiscal multiplier area is based on two main methodologies. The first one is Structural Vector Auto Regression models (SVAR). The second are Dynamic Stochastic General Equilibrium (DSGE) models. The (SVAR) approach in investigation fiscal multiplier was introduced (Blanchard and Perotti, 2002) using quarterly data of government expenditure, taxes and output for united states. Ilzetzki et al. (2013) Auerbach and Gorodnichenko (2012a, b) and Elkhdari et al. (2018) are examples of studies applied SVAR. While Christiano et al. (2011), Zubairy (2014) and Bhattarai and Trzeciakiewicz (2017) are examples of studies applied DSGE Model. Fatas and Mihov (2001) applied SVAR using Cholesky ordering identification which imposing that the unexpected changes in GDP will not have an impact on government spending within one quarter using US quarterly data they found that the fiscal multiplier is $>1$. Blanchard and Perotti (2002) refined the SVAR approach by applying non recursive identific ation strategy by using external information on the elasticity of fiscal variable, they found the spending multiplier is close to one. An alternative identification strategy used by Leigh et al. (2010) is narrative approach which used to improve the identification strategy of the exogenous fiscal shock. The latter identification strategy depends on the previous knowledge of the discretionary fiscal actions obtained from governmental budget documents. Leigh et al. (2010) applied the narrative approach to identify fiscal policy actions implemented in 17 OECD countries to reduce budget deficit such actions are not taken to address contemporaneous macro economic activities. Auerbach and Gorodnichenko (2012a, b) extended a SVAR Model for united states by using a regime switching model to differentiate between recession and expansion time. They found that the fiscal multiplier was 0.6 in expansion and 2.5 during expansion. While (Auerbach and Gorodnichenko, 2012a, b) by applying an augmented vector autoregressive model for OECD countries. They confirmed their previous results of larger fiscal multiplier impact during expansion and lower during recession. Ferraresi et al. (2015) the study applied Threshold Vector Auto Regression (TVAR) Model using quarterly data for US during the period 1984-2001. The study found an evidence of higher fiscal multiplier when the USA economy in a tight credit regime. Ilzetzki et al. (2013) estimated panel SVAR for 20 developed countries and 24 developing countries and divided these countries to subgroups distinguished by the level of development, the exchange rate regime, openness to trade and public indebtedness. The study found that the multiplier effect is low or even negative when the public debt is high and the multiplier is lower in open economy and countries with flexible exchange rate regime. Also, Corsetti et al. (2012) show that the multiplier effect differ according to the economic environment i.e., exchange rate regime, public indebtedness, health and financial system. Using SVAR for 17 OECD countries the study found that the multiplier is larger during financial crisis for countries with fixed exchange rate regime. Afonso et al. (2018) applied TVAR using quarterly data for US, UK, Germany and Italy for the period 1980-2014. The study found that the multiplier effect depends on the financial stress in the economy.

Upon previous literature review one can realize that fiscal multipliers are a controversial topic. It depends on the different characteristics of each country like level of development, exchange rate regime, etc. Also, it depends on the methodology used in the estimation of fiscal multiplier.

In this study, we will use the non recursive identification strategy similar to Blanchard and Perotti (2002) using Egyptian quarterly data. This study is a first attempt to provide empirical estimates for fiscal multiplier using Blanchard and perotti (2002) identification method for Egypt. There are only three examined this topic in the Egyptian economy. First, Alnashar (2017) the study applied VECM using quarterly data for the period 2005-2016. The estimated fiscal multiplier was found 0.06 . The researcher justified the low fiscal multiplier in Egyptian case due to the continuous increase in interest rate and rising capital inflow followed by currency appreciation, in turn raise the price of domestic products and increase the importation. Second, Sarangi and Bonin (2017) studied fiscal policy for $10 \mathrm{Arab}$ countries including Egypt. The study calculated the fiscal multiplier for different categories of spending in case in Egypt for the period 1990-2015 using annual data and SVAR with Cholesky identification. The fiscal multiplier for current spending was 0.1 and for capital spending was 0.16. Third, Cerisola et al. (2015). Estimated fiscal multiplier for19 MENA (Middle East and North Africa) countries including Egypt as an oil importing country. By applying PSVAR using annual data from 1990-2008. The fiscal multiplier for current spending was found 0.6 .

An overview on the Egyptian macroeconomic policy: Egypt suffers from significant fiscal deficit due to high expenditure and the vulnerability of government revenues. However, the fiscal deficit in Egypt isn't merely a reflection of accelerated output growth. The increase in public expenditure is not necessarily improve economic growth level but on the contrary may be some times 


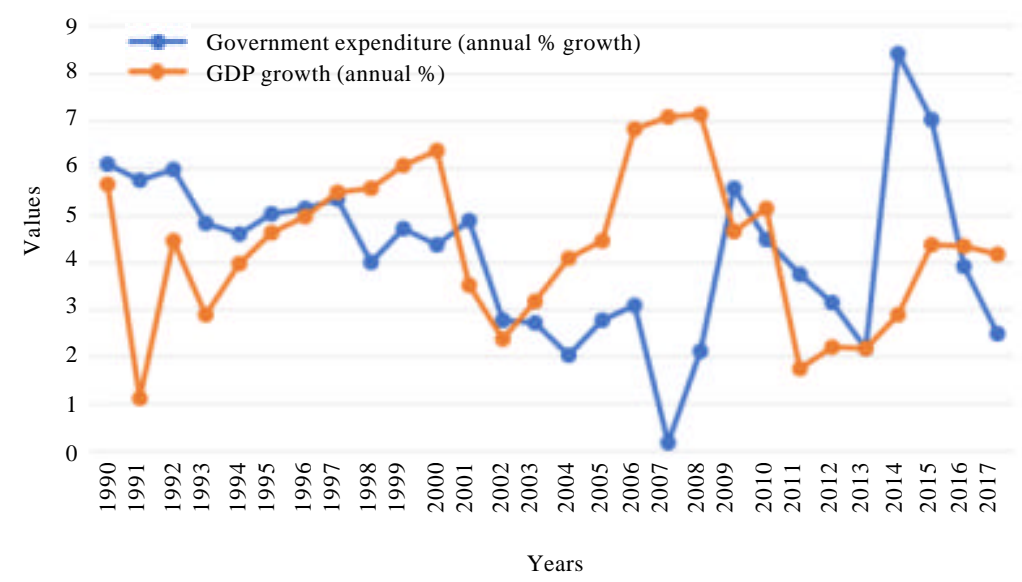

Fig. 1: Government expenditure vs. economic growth (1990-2015) (Author depending on world development indicators 2019)

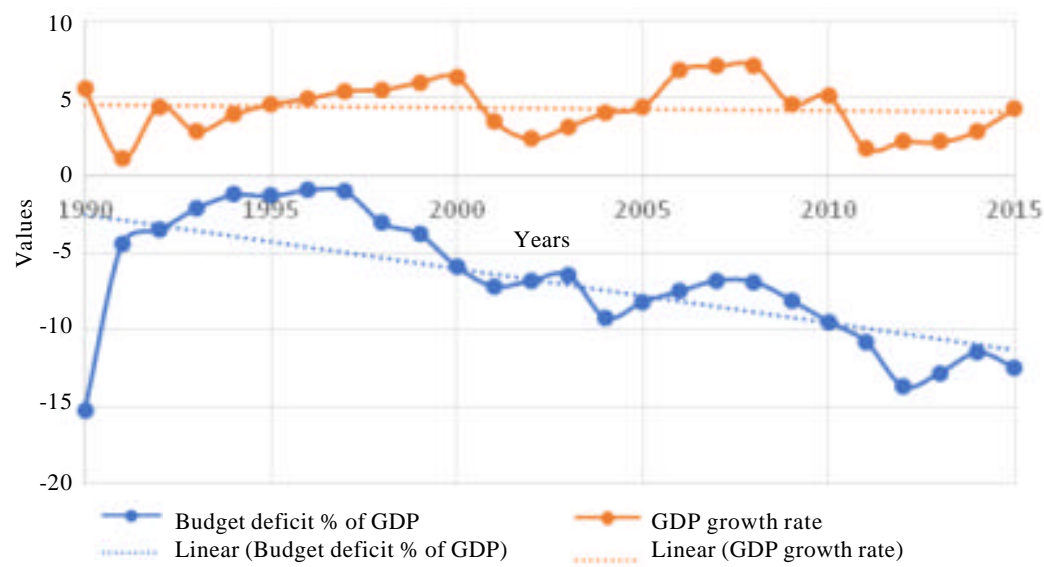

Fig. 2: Budget deficit \% GDP vs. economic growth (1990-2015) (Author using the annual report of the Central Bank of Egypt for budget deficit and world development indicators 2019 for GDP growth rate)

accompanied by a deterioration in the economic growth levels. Because most of the rising expenditures are devoted to the continuous rise in subsidies, debt services cost and public wages that together comprise $75 \%$ of public expenditure in Egypt.

As shown from Fig. 1 in 1990's the average annual growth rate of government expenditure was around $6 \%$ while the average GDP growth rate was only $4 \%$. For example, in 1991 the annual growth rate of government expenditure was $6 \%$, the annual GDP growth rate was only $1 \%$. Also, in 2011, the annual growth rate in 2011-2012 was around $5 \%$ while the annual GDP growth rate was around $1.5 \%$. From Fig. $1 \mathrm{GDP}$ is under performed as there are several stag nation in the growth rate despite the higher government expenditure. Thus, the small fiscal multiplier can be expected in Egypt because despite the rising public expenditure, the economic growth has a declining trend. While Fig. 2 illustrate that the government budget deficit reaching $10.8 \%$ of GDP in 2011/2012. This could be because the political turmoil in 25th January, meeting the social and economic needs have been triggered from this turmoil have burdens the Egyptian budget deficit and significantly affected the economic growth in Egypt. Despite there is an increasing trend for budget deficit, the GDP growth rate was mostly decreasing during the period the period of the study.

Data and methodology: Following Blanchard and Perotti (2002) the study estimate a three variable SVAR Model using taxation, spending and output as endogenous variables. In order to estimate a robust SVAR Model, it is recommended to have at least 15 years of quarterly data. While annual data for Egypt are available for the period 1990-2015, quarterly data are only 
available for the period 2006-2015. Therefore, following (Elkhdari et al., 2018) the unavailable quarterly data are extrapolated based on the seasonality observed during the period for which data is available. We also, used Denton methodology (Denton, 1971) and found the data generated is very similar to the data extrapolated using the historical seasonality, then all the variables are $\log$ transformed.

\section{MATERIALS AND METHODS}

In this study, we are going to run SVAR Model to estimate the size of the fiscal multiplier in Egypt during the period 1990-2015 using the non-recursive approach used by Blanchard and Perotti (2002). Then we are going to apply the recursive (The Cholesky decomposition) approach as a robustness check.

The SVAR specification: The reduced form VAR is defined by the following Eq. 4:

$$
\mathrm{X}_{\mathrm{t}}=\mathrm{C}(\mathrm{L}) \mathrm{X}_{\mathrm{t}-1}+\mathrm{U}_{\mathrm{t}}
$$

where, $X_{t} \equiv\left[\begin{array}{c}g_{t} \\ y_{t} \\ r_{t}\end{array}\right]$ is a vector of three variables spending, output and taxes for quarter $t, C(L)$ is $n \times n$ matrix in the operator of lag length $L$ for q quarters. $U_{t} \equiv\left[\begin{array}{c}u_{t}^{x} \\ u_{t}^{g} \\ u_{t}^{y}\end{array}\right] i$

As reduced form disturbances are correlated, the reduced form has to be transformed into structural model to identify structural shocks. Pre-multiplying both sides of Eq. 4 by $A_{0}$ matrix yields the structural form. Where $A_{0}$ is a full rank matrix which defines the contemporaneous interrelationships between the endogenous variables:

$$
\mathrm{A}_{0} \mathrm{X}_{\mathrm{t}}=\mathrm{A}_{0}(\mathrm{~L}) \mathrm{X}_{\mathrm{t}-1}+\mathrm{Be}_{\mathrm{t}}
$$

The relationship between the structural disturbances $e_{t}$ and the reduced form disturbances $u_{t}$ is described by:

$$
\mathrm{A}_{0} \mathrm{U}_{\mathrm{t}}=\mathrm{Be}_{\mathrm{t}}
$$

In structural model, the error term is assumed to be uncorrelated within each other i.e., the covariance matrix of the structural error covariance matrix $E\left(u_{t} u_{t}^{\prime}\right)=\Sigma_{u}$ is diagonal. According to Perotti (2002) the reduced form residuals $u_{t}^{r}, u_{t}^{g}$ and $u_{t}^{y}$ can be found through linear combination of three components. First, the automatic response of taxes and government spending to innovation in output. Second, the symmetric discretionary response of policy makers to output. Third, the random discretionary shocks to fiscal policy. In this study, we will show the case of government spending shocks in which government spending decisions are made before tax. The linear combination of structural shocks according to (Perotti, 2002) can be shown as follows:

$$
\begin{aligned}
& u_{t}^{g}=\alpha_{y}^{g} u_{t}^{y}+\beta_{r}^{y} e_{t}^{r}+\beta_{g}^{g} e_{t}^{g} \\
& u_{t}^{y}=\alpha_{g}^{y} u_{t}^{g}+\alpha_{r}^{y} u_{t}^{r}+\beta_{y}^{y} e_{t}^{y} \\
& u_{t}^{r}=\alpha_{y}^{r} u_{t}^{r}+\beta_{g}^{r} e_{t}^{g}+\beta_{r}^{r} e_{t}^{r}
\end{aligned}
$$

where, $\mathrm{u}_{\mathrm{t}}^{\mathrm{r}}, \mathrm{u}_{\mathrm{t}}^{\mathrm{g}}$ and $\mathrm{u}_{\mathrm{t}}^{\mathrm{y}}$ are the unexpected movements in the taxes, spending and output, respectively. The unexpected movements refer to the residuals in the VAR estimates or the part that is not explained by the VAR Model. The mutually uncorrelated structural shocks are represented by $e_{t}{ }^{r}, e_{t}^{g}$ and $e_{t}^{y}$ they capture the share of $U_{t}$ due to exogenous factors i.e., the structural shocks among others including demand and supply shocks, monetary and fiscal shocks and technology shocks.

Equation 7 implies that the forecast error of government spending are mix of errors and structural shocks. In other words, the unexpected movement in government spending is due to surprises in GDP, structural shocks to taxes and structural shocks to government spending. As mentioned before, at high frequency data, there is no discretionary within the period (quarter) i.e., any unexpected movement in GDP will not affect government spending. Thus, coefficient $\alpha_{\mathrm{y}}{ }^{\mathrm{g}}$ will always be zero. Hence, the government isn't looking at what's going on with GDP within the quarter to change spending. Also, the government spending decisions go before structural shocks to taxes, therefore, $\beta_{\mathrm{r}}^{\mathrm{g}}$ will be zero.

In Eq. 8 the forecast error of GDP is due to surprise movement in government spending, surprise movement in taxes and structural shocks to GDP itself. The elasticities of GDP to government spending $\alpha_{\mathrm{g}}^{\mathrm{y}}$ and to taxes $\alpha_{\mathrm{r}}^{\mathrm{y}}$ will be obtained directly from the VAR estimation. Despite incase of (Blanchard and Perotti, 2002) these two coefficients have been estimated outside the VAR using Instrumental Variable (IV) estimation.

Equation 9 forecast errors in taxes are due to surprise movements in GDP, structural shocks to government spending and structural shocks to taxes itself. Blanchard and Perotti (2002) constructed the elasticity to 
output of taxes which is the coefficient $\alpha_{\mathrm{y}}{ }^{\mathrm{r}}$, they follow the procedure done usually at OECD where they computed the elasticity of tax revenue to the base and the elasticity of the tax base to GDP. Blanchard and Perotti (2002) calculated a weighted average during the estimation period. In case of Blanchard and Perotti (2002) this coefficient was 2.08. However, Caldara and Kamps (2017) approved the uncertainty of the calculated value of the elasticity of tax revenue by Blanchared and Perotti (2002). Caldara and Kamps (2017) showed that the standard identification scheme imply different priors on elasticities generating a large dispersion in multiplier estimate and they surveyed the existing to derive distributions on elasticities that encompass the existing empirical evidence, then they estimate fiscal multiplier based on these prior distribution. Due to data limitation, since, the time series available for Egypt are very short, econometrics estimates of elasticity of tax will be of questionable accuracy. Some studies like Leeper et al. (2010) used the simplistic assumption that the elasticity of tax revenue to be 1 . However, a study of world bank by Alba et al. (2004) also showed the difficulty of calculating this coefficient incase of Egypt. And by observing data, they provide the evidence that the elasticity of the elasticity of tax revenue isn't equal to one in Egypt. Then we cannot move beyond to the simplistic assumption of the elasticity of tax revenue to be 1 .

Then, in order to get around data limitation, we are going to use the calculated value by IMF (2011) for the elasticity of tax revenue for high debt developing countries. In this study this coefficient will be (1.5) and will be introduced as a number to matrix (A). Finally, the coefficient $\beta_{\mathrm{g}}{ }^{\mathrm{r}}$ in Eq. 9 is estimated within the VAR. Equations $7-9$ can be re written in a matrix form as follows:

$$
\begin{gathered}
{\left[\begin{array}{ccc}
1 & -\alpha_{\mathrm{y}}^{\mathrm{g}} & -\alpha_{\mathrm{r}}^{\mathrm{g}} \\
-\alpha_{\mathrm{g}}^{\mathrm{y}} & 1 & -\alpha_{\mathrm{r}}^{\mathrm{y}} \\
-\alpha_{\mathrm{g}}^{\mathrm{r}} & -\mathrm{a}_{\mathrm{y}}^{\mathrm{r}} & 1
\end{array}\right] \times\left[\begin{array}{l}
\mathrm{u}_{\mathrm{t}}^{\mathrm{g}} \\
\mathrm{u}_{\mathrm{t}}^{\mathrm{y}} \\
\mathrm{u}_{\mathrm{t}}^{\mathrm{r}}
\end{array}\right]=\left[\begin{array}{ccc}
\beta_{\mathrm{g}}^{\mathrm{g}} & 0 & \beta_{\mathrm{r}}^{\mathrm{g}} \\
0 & \beta_{\mathrm{y}}^{\mathrm{y}} & 0 \\
\beta_{\mathrm{g}}^{\mathrm{r}} & 0 & \beta_{\mathrm{r}}^{\mathrm{r}}
\end{array}\right] \times\left[\begin{array}{l}
\mathrm{e}_{\mathrm{t}}^{\mathrm{g}} \\
\mathrm{e}_{\mathrm{t}}^{\mathrm{y}} \\
\mathrm{e}_{\mathrm{t}}^{\mathrm{r}}
\end{array}\right]} \\
{\left[\begin{array}{ccc}
1 & -\alpha_{\mathrm{y}}^{\mathrm{g}} & -\alpha_{\mathrm{r}}^{\mathrm{g}} \\
-\alpha_{\mathrm{g}}^{\mathrm{y}} & 1 & -\alpha_{\mathrm{r}}^{\mathrm{y}} \\
-\alpha_{\mathrm{g}}^{\mathrm{r}} & -\alpha_{\mathrm{y}}^{\mathrm{r}} & 1
\end{array}\right] \times \mathrm{U}_{\mathrm{t}}=\left[\begin{array}{ccc}
\beta_{\mathrm{g}}^{\mathrm{g}} & 0 & \beta_{\mathrm{r}}^{\mathrm{g}} \\
0 & \beta_{\mathrm{y}}^{\mathrm{y}} & 0 \\
\beta_{\mathrm{g}}^{\mathrm{r}} & 0 & \beta_{\mathrm{r}}^{\mathrm{r}}
\end{array}\right] \times \mathrm{E}_{\mathrm{t}}} \\
\text { i.e., } \mathrm{AU}_{\mathrm{t}}=\mathrm{BE}_{\mathrm{t}}
\end{gathered}
$$

Where, $E_{t} \equiv\left[\begin{array}{c}e_{t}^{r} \\ e_{t}^{g} \\ e_{t}^{y}\end{array}\right]$
Since, we use quarterly data according to (Blanchard and Perotti, 2002) government isn't able to react quickly within the same quarter to the macroeconomic cycle because policy responses involve many agents like parliament, central bank and therefore, take more than a quarter as it usually require more time to produce appropriate responses. For example, new spending decision usually has to pass before the parliament and has to be accepted in order to be implemented. Therefore, as shown from Eq. 10 the reduced form fiscal shocks capture only the automatic response of fiscal variables to economic activity. This last point implies that $\alpha_{\mathrm{r}}^{\mathrm{g}}=\alpha_{\mathrm{g}}^{\mathrm{r}}=0$. We choose the number of lags according to Akaike Information Criterion. A 2-lag vector autoregressive model is estimated. Finally, as a robustness check, we also apply the SVAR using the Cholesky identification method.

The recursive approach (a robustness check): To check the robustness of our finding that suggests a low fiscal multiplier turn into negative, we apply SVAR Model using the Cholesky decomposition of variance-covariance matrix of VAR residual scheme is used to identify the structural shocks (the government spending $\mathrm{e}_{\mathrm{g}}$ and the tax shock $\mathrm{e}_{\mathrm{g}}$ ). It is necessary to impose restrictions assuming that some structural shocks have no contemporaneous effects on some endogenous variables. According to Cholesky decomposition the matrix $\mathrm{A}_{0}$ is identified as a lower triangular matrix and matrix $B$ as $n$-dimensional identity matrix. It is essential to take into account the ordering of the variables to investigate the structural shocks. Following previous studies like Fatas and Mihov (2001) and Favero (2002) the variables are ordered as follows: government spending, real output and net taxes. This ordering assuming that; government spending is not contemp oraneously affected by any of the shocks, real out put is contemporaneously affected only by the government spending shocks, taxes is contemporaneously influenced by the shocks of both government spending and real output. According to the Cholesky decomposition Eq. 6 becomes:

$$
\left[\begin{array}{ccc}
1 & 0 & 0 \\
-\alpha_{g}^{y} & 1 & 0 \\
-\alpha_{g}^{r} & -\alpha_{y}^{r} & 1
\end{array}\right] \times\left[\begin{array}{c}
u_{t}^{g} \\
u_{t}^{y} \\
u_{t}^{r}
\end{array}\right]=\left[\begin{array}{lll}
1 & 0 & 0 \\
0 & 1 & 0 \\
0 & 0 & 1
\end{array}\right] \times\left[\begin{array}{c}
e_{t}^{g} \\
e_{t}^{y} \\
e_{t}^{r}
\end{array}\right] 7
$$

After the identification of the VAR Model, the impulse response functions are obtained. 


\section{RESULTS AND DISCUSSION}

First the data will be tested for the existence of unit root using the Augmented dickey-Fuller test. As shown from Table. 1 there is a unit root in the level of the variables but the null hypothesis of a unit root can be rejected for all the variables in first difference. Given that the series are nonstationary, SVAR Model is estimated in level of first differences. We choose the number of lags according to Akaike Information Criterion. A 2 lag Vector autoregressive model is estimated.

Impulse response function for non-recursive approach: As shown in Fig. 3 the fiscal multiplier was around positive (0.9) at the first year, then it turned to be negative in the second year. Our results are in line with prementioned studies applied in the Egyptian case Alnashar, (2017) Cerisola et al., (2015) and Sarangi and Bonin (2017) who found the effect of spending multiplier in Egypt is very negligible. Also, our results are in line with (Hory, 2016) who applied panel vector autoregressive model for 48 emerging and advanced economies and found find a very small multiplier (around zero) for developing countries this results are also, on line with (Shen et al., 2018) countries that rely more on external aid to finance public spending often have lower fiscal multiplier than those that rely more on tax burdens on their citizens. The result is in line also with Ilzetzki et al. (2013) and Muller (2014) that the multiplier effect is very low or negative in high debt countries.

Forecast error variance decomposition for the non-recursive model: Finally, we investigated whether government expenditure is indeed an important driver of GDP in Egypt. Table. 2 the contribution of the different shocks to the variance of RGDP in Egypt. The forecast error variance decomposition shows that the government expenditure would account for only about $0.576489 \%$ of the variance generated by structural shocks in the short-run and about $0.054499 \%$ in the medium term. This result confirm our estimation of the fiscal multiplier

Table 1: Augmented Dickey - Fuller unit root tests

\begin{tabular}{ll}
\hline Variable & \multicolumn{1}{c}{ t-statistic } \\
\hline LOG(GOV) & \\
Level & $-0.424185 \mathrm{I}(1)$ \\
1st difference & $-3.118596^{*}$ \\
LOGGDP & \\
Level & $-0.906978 \mathrm{I}(1)$ \\
1st difference & $-2.863389^{*}$ \\
LOGNETTAX & \\
Level & $1.433966 \mathrm{I}(1)$ \\
1st difference & $-4.610779^{*}$ \\
\hline *Denotes significance at the 5\% level &
\end{tabular}

which was positive in the first quarter and turned into negative in the second year which is an indication of diminishing the role of the government expenditure in driving GDP in Egypt.

Table 2: Egyptian RGDP forecast error variance decomposition (non-recursive model)

Percentage of the forecast error of explained by shocks in government expenditure

\begin{tabular}{lccc} 
Quarters & Government expenditure & RGDP & Net tax \\
\hline 1 & 1.905337 & 56.82123 & 41.27343 \\
2 & 1.049924 & 54.39085 & 44.55923 \\
3 & 0.576489 & 51.95027 & 47.47324 \\
4 & 0.323140 & 49.56002 & 50.11684 \\
5 & 0.195118 & 47.27143 & 52.53345 \\
6 & 0.133185 & 45.11451 & 54.75230 \\
7 & 0.101822 & 43.10208 & 56.79610 \\
8 & 0.081998 & 41.23509 & 58.68291 \\
9 & 0.066132 & 39.50699 & 60.42687 \\
10 & 0.054499 & 37.90687 & 62.03863 \\
\hline
\end{tabular}
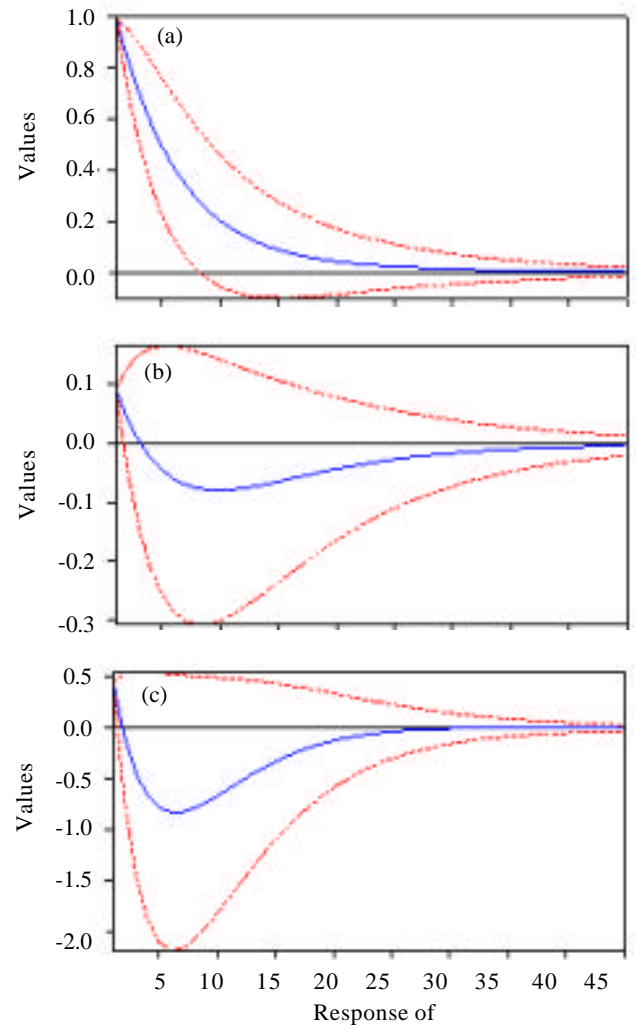

D(LOGRGOV) to shock 1

Fig. 3: Response of endogenous variables to the government expenditure shock (non-recursive approach): a) Response to user specified innvotation (FACTI1) \pm 2 S.E respomse of D (LOGRGOV) to shock 1, (b) Response of D (LOGRGDP to Shock 1) and (c) Response of D (LOGNETTAX) to shock 1 
The Soc. Sci., 14 (6): 255-265, 2019

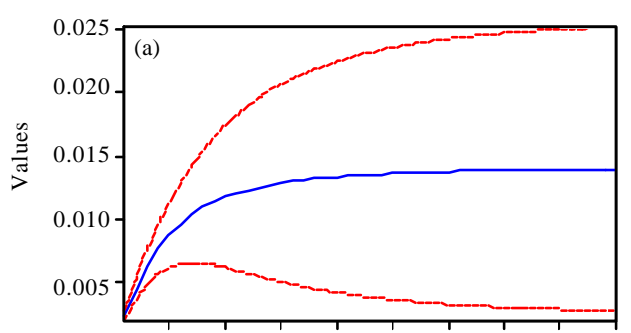

Table 3: Egyptian RGDP forecast error variance decomposition (recursive model'a robustness check)

\begin{tabular}{lccc}
\hline & \multicolumn{2}{l}{$\begin{array}{l}\text { Percentage of the forecast error of explained by shocks in } \\
\text { government expenditure }\end{array}$} \\
Quarters & Government expenditure & RGDP & Net tax \\
\hline 1 & 1.906267 & 98.09373 & 0.000000 \\
2 & 1.050402 & 98.83672 & 0.112877 \\
3 & 0.576732 & 99.04250 & 0.380767 \\
4 & 0.323265 & 98.90513 & 0.771607 \\
5 & 0.195189 & 98.54682 & 1.257996 \\
6 & 0.133232 & 98.05044 & 1.816327 \\
7 & 0.101858 & 97.47115 & 2.426995 \\
8 & 0.082028 & 96.84371 & 3.074267 \\
9 & 0.066156 & 96.18798 & 3.745864 \\
10 & 0.054517 & 95.51306 & 4.432427 \\
\hline
\end{tabular}

Forecast error variance decomposition for the recursive Model (a robustness check): As shown in Table 3 The shock to government expenditure account for $0.576732 \%$ variation of the fluctuation in GDP in the short-run while a shock to government expenditure can cause about $0.054517 \%$ fluctuation in GDP in the medium term. Finally, The robustness test leave our results not changed. The fiscal multiplier was small positive value which turned into negative like the results abstained earlier from the recursive approach.

In this study, we empirically measure the size of the fiscal multiplier in Egypt during the period (1990-2015) using quarterly data. The fiscal multiplier is estimated to be very low which is an indication of a weak impact of government spending on real GDP during the period of the study. The empirical measurement of the fiscal multiplier indicate as shown in Fig. 5 a low multiplier effect which turn into negative. This could be justified that the expansionary fiscal policy as shown in Fig. 5 was usually accompanied by a deterioration in the exchange rate, despite the depreciation of the exchange rate Fig. 5 indicate a continuous deficit in the trade balance. The figure shows the time series variation of real output after a government spending shock. The red dashed lines show $95 \%$ confidence intervals. Blue solid line shows direct projection of point estimates. The continuous trade deficit could be attributed to the higher level of imports in comparison to the exports. This could be an evidence that most of the government spending isn't productive spending. However, as shown in Fig. 6, most of the Egyptian government spending is for consumption purposes. Government expenditures are mostly allocated to worker wages, interest payments on domestic and the high external debts and to subsidies. While as shown in Fig. 6 the domestic investment spending is only $17 \%$ of GDP during 1990-2017 while the consumption expenditure was more than $80 \%$ on average. 


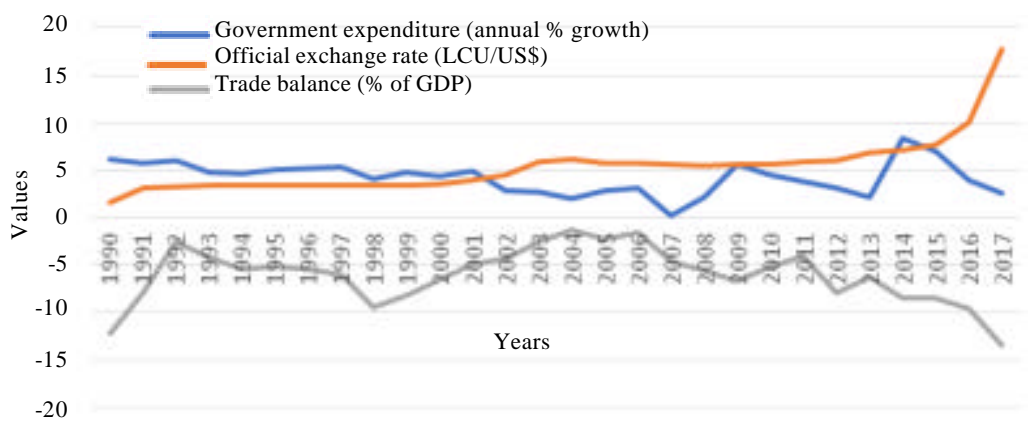

Fig. 5: Trade deficit, exchange rate and government expenditure (1990-2017) (author depending on World Development Indicators 2019)

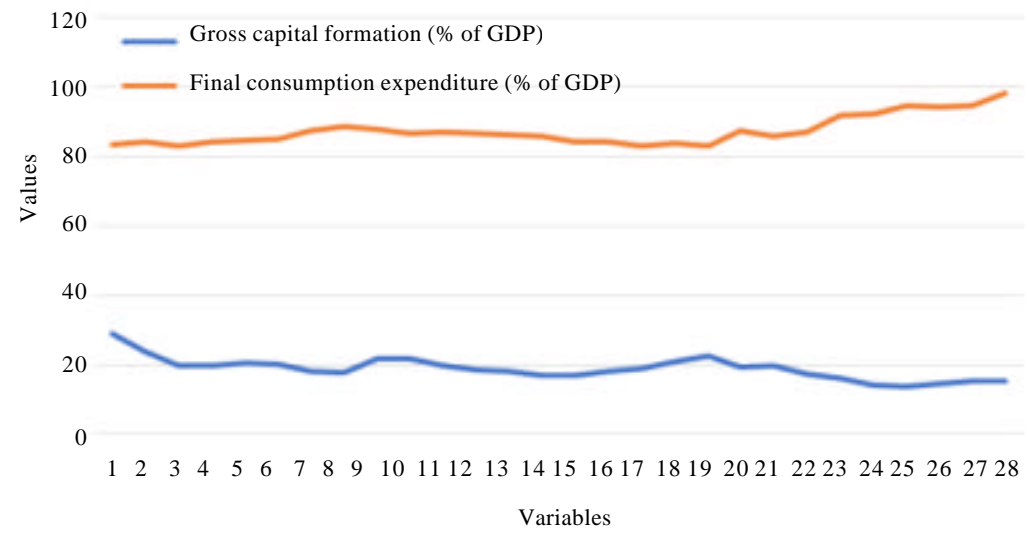

Fig. 6: Gross domestic investment vs. consumption expenditure (1990-2017) (author depending on World Development Indicators 2019)

\section{CONCLUSION}

Then, the government authorities should not rely solely on increasing the amount of spending but a series of complementary actions are needed to improve the efficiency of public expenditure like, direct more spending toward productive investment, the fight against corruption and tighten control over the performance of the government institutions. Moreover, cutting government spending and increasing taxes will be more efficient case way to increase economic growth in the Egyptian specifically in case of negative fiscal multipliers.

\section{LIMITATION}

Despite the important contributions have been made in estimating the magnitude of fiscal multiplier. Measuring aunique size of fiscal multiplier still a challenging task. The limitation of our analysis motivates future work to create a longer quarterly dataset and develop a realistic DSGE Model.

\section{STATEMENT OF SIGNIFICANCE}

Knowing the size of fiscal multipliers is important for governments before making the decision of applying expansionary or contractionary fiscal policies. Basically, if fiscal multiplier is high, fiscal policy has a large impact on the real economic output. And it may also, indicate that the government must be carful when considering austerity actions. In contrast, if the fiscal multiplier is small, this indicates the expansionary fiscal policy have a magnitude impact on the economy, also, cutting government spending and increasing taxes will be more efficient in case of negative fiscal multipliers.

\section{REFERENCES}

Afonso, A., J. Baxa and M. Slavik, 2018. Fiscal developments and financial stress: A threshold VAR analysis. Empirical Econ., 54: 395-423. 
Alba, P., S. Shawarby and F. Iqbal, 2004. Fiscal and public debt sustainability in Egypt. Middle and North Africa Working Paper No. 97, The World Bank, Washington, DC. USA. http:// www.eces.org.eg/MediaFiles/Uploaded_Files/\%7B 40A5FE20-E342-4B76-9BCD-E33ABDF85624\% 7D_ECESWP97.pdf

Alnashar, S.B., 2017. Egypt's government spending multiplier: Its size and determinants. Working Papers No. 1165, The Economic Research Forum, Dokki, Giza, Egyp. https://erf.org.eg/wpcontent/uploads/2017/12/1165.pdf

Auerbach, A.J. and Y. Gorodnichenko, 2012a. Fiscal Multipliers in Recession and Expansion. In: Fiscal Policy After the Financial Crisis, Alesina, A. and F. Giavazzi (Eds.). University of Chicago Press, Chicago, Illinois, USA., ISBN-13:978-0-226-01844-7, pp: 63-98.

Auerbach, A.J. and Y. Gorodnichenko, 2012a. Measuring the output responses to fiscal policy. Am. Eco. J. Econ. Policy, 4: 1-27.

Bhattarai, K. and D. Trzeciakiewicz, 2017. Macroeconomic impacts of fiscal policy shocks in the UK: A DSGE analysis. Econ. Modell., 61: 321-338.

Blanchard, O. and R. Perotti, 2002. An empirical characterization of the dynamic effects of changes in government spending and taxes on output. Q. J. Econ., 117: 1329-1368.

Caldara, D. and C. Kamps, 2017. The analytics of SVARs: A unified framework to measure fiscal multipliers. Rev. Econ. Stud., 84: 1015-1040.

Cerisola, M.D., C. Abdallah, V. Davies and M. Fischer, 2015. Assessing the impact of fiscal shocks on output in MENAP countries. IMF, International Monetary Fund Washington, DC. USA. https://www.elibrary.imf.org/view/IMF005/224059781498383905/22405-9781498383905/224059781498383905.xml?redirect $=$ true

Christiano, L., M. Eichenbaum and S. Rebelo, 2011. When is the government spending multiplier large?. J. Political Econ., 119: 78-121.

Corsetti, G., A. Meier and G.J. Muller, 2012. What determines government spending multipliers?. Econ. Policy, 27: 521-565.

Denton, F.T., 1971. Adjustment of monthly or quarterly series to annual totals: An approach based on quadratic minimization. J. Am. Stat. Assoc., 66: 99-102.

Elkhdari, M., M. Souissi and M.A. Jewell, 2018. Empirical estimation of fiscal multipliers in MENA oil-exporting countries with an application to Algeria. IMF Working Paper No. 18/124, (IMF) International Monetary Fund, Washington, DC. USA. https://papers.ssm.com/sol3/papers.cfm?abstract_ id=3221 208 .
Fatas, A. and I. Mihov, 2001. The effects of fiscal policy on consumption and employment: Theory and evidence. CEPR Discussion Paper. No. 2760, http://faculty.insead.edu/fatas/fiscal.pdf

Favero, C.A., 2002. How do European monetary and fiscal authorities behave?. CEPR Discussion Paper No. 3426, enter for Economic and Policy Research, Washington, DC. USA. https://papers.ssin.com/ sol3/papers.cfm?abstract_id=323361

Ferraresi, T., A. Roventini and G. Fagiolo, 2015. Fiscal policies and credit regimes: A TVAR approach. J. Appl. Econ., 30: 1047-1072.

Gechert, S. and H. Will, 2012. Fiscal multipliers: A meta regression analysis. IMK Working Paper No. 97, Institut Fur Makrookonomie and Konjunkturforschung (IMK), Dusseldorf, Germany. https://www.econstor.eu/handle/10419/105964

Hicks, J.R., 1937. Mr. Keynes and the classics: A suggested interpretation. Econometrica, 5: 147-159.

Hory, M.P., 2016. Fiscal multipliers in emerging market economies: Can we learn something from advanced economies?. Intl. Econ., 146: 59-84.

IMF, 2011. World economic Outlook database. International Monetary Fund, http://www. $\mathrm{imf}$.org/external/pubs/ft/weo/2011/01/weodata/weo selgr.aspx.

Ilzetzki, E., E.G. Mendoza and C.A. Vegh, 2013. How big (small?) are fiscal multipliers?. J. Monetary Econ., 60: 239-254.

Leeper, E.M., M. Plante and N. Traum, 2010. Dynamics of fiscal financing in the United States. J. Econometrics, 156: 304-321.

Leeper, E.M., N. Traum and T.B. Walker, 2017. Clearing up the fiscal multiplier morass. Am. Econ. Rev., 107: 2409-2454.

Leigh, D., P. Devries, C. Freedman, J. Guajardo and D. Laxton et al., 2010. Will it hurt? Macroeconomic effects of fiscal consolidation. World Econ. Outlook, 93: 124-124.

Muller, G.J., 2014. Fiscal austerity and the multiplier in times of crisis. Ger. Econ. Rev., 15: 243-258.

Perotti, R., 2002. Estimating the effects of fiscal policy in OECD countries. ECB Working Paper No. 168, Centre for Economic Policy Research, London, England. https://papers.ssrn.com/sol3/papers.cfm?abstract_ $\mathrm{id}=358082$

Sarangi, N. and J.V. Bonin, 2017. Fiscal policy on public social spending and human development in Arab countries. E/ESCWA/EDD/2017/Technical Paper 13, United Nations Economic and Social Commission for Western Asia, Beirut, Lebanon. https://www. unescwa.org/publications/fiscal-policy-public-socialspending-arab-countries 
The Soc. Sci., 14 (6): 255-265, 2019

Shen, W., S.C.S. Yang and L.F. Zanna, 2018. Government spending effects in low-income countries. J. Dev. Econ., 133: 201-219.
Zubairy, S., 2014. On fiscal multipliers: Estimates from a medium scale DSGE Model. Intl. Econ. Rev., 55: 169-195. 